\title{
Obesity, HDL and Breast Cancer
}

\author{
Viroj Wiwanitkit
}

Received: 14 June 2012 / Accepted: 9 July 2012 / Published online: 20 July 2012

(C) Indian Association of Surgical Oncology 2012

\section{Letter to editor}

Sir, the recent report entitled "Correlation Between Obesity and High Density Lipoprotein Cholesterol (HDL-C) in Breast Cancer Patients of Southern Rajasth" is very interesting [1]. Inamdar et al. concluded that "only low HDL-C level had significant correlation with breast cancer and none of the other anthropometric measurements were associated with breast cancer [1]." As Inamdar et al. noted, further systematic assessment is required. Indeed, low HDL-C level is reported for its association with increased postmenopausal breast cancer risk [2]. However, the main problem for final conclusion on such relationship is confounding factors. It should be noted that the metabolic syndrome, which is the larger superset of dyslipidemia, is also mentioned for its relationship to postmenopausal breast cancer risk $[3,4]$. The more in depth genetic underlying which determine the lipid phenotype might be the solution for clarifying the clinical relationship.

\section{References}

1. Inamdar P, Mehta G (2011) Correlation between obesity and high density lipoprotein cholesterol (HDL-C) in breast cancer patients of Southern Rajasthan. Indian J Surg Oncol 2(2):118121

2. Furberg AS, Veierød MB, Wilsgaard T, Bernstein L, Thune I (2004) Serum high-density lipoprotein cholesterol, metabolic profile, and breast cancer risk. J Natl Cancer Inst 96(15):11521160

3. Capasso I, Esposito E, Pentimalli F, Crispo A, Montella M, Grimaldi M, De Marco M, Cavalcanti E, D'Aiuto M, Fucito A, Frasci G, Maurea N, Esposito G, Pedicini T, Vecchione A, D'Aiuto G, Giordano A (2011) Metabolic syndrome affects breast cancer risk in postmenopausal women: National Cancer Institute of Naples experience. Canc Biol Ther 10(12):1240 1243

4. Petrovanu C, Coman AE, Murariu GC, Petrovanu R (2008) Metabolic syndrome and breast cancer risk in post-menopausal women. Rev Med Chir Soc Med Nat Iasi 112(3):630-634
V. Wiwanitkit $(\triangle)$

Wiwanitkit House,

Bangkhae,

Bangkok, Thailand

e-mail: wviroj@yahoo.com

V. Wiwanitkit

Joseph Ayobabalola University,

Ikeji-Arakeji, Nigeria 